\title{
Polihexanide Solution
}

\author{
National Cancer Institute
}

\section{Source}

National Cancer Institute. Polihexanide Solution. NCI Thesaurus. Code C121637.

A solution containing the polymer polihexanide, with potential antimicrobial, disinfectant and wound healing activities. Upon application to a wound, polihexanide strongly binds to the wound surface and exerts an antiseptic effect through the binding of the positively charged guanidine groups of polihexanide with the negatively charged phospholipids of the bacterial cell membrane. This compromises the stability of the bacterial cell membrane, which results in the leakage of cytoplasmic components and leads to bacterial cell death. In addition, polihexanide accelerates wound healing by promoting epithelial cell migration and proliferation. 